\title{
PIERCE v. COOK \& CO.: CHANGE IN STATE LAW AS A GROUND FOR RELIEF FROM
}

\author{
A FEDERAL JUDGMENT
}

A supervening change in controlling law generally is not held to justify relief from a final judgment under rule $60(\mathrm{~b})^{1}$ of the Federal Rules of Civil Procedure. The Court of Appeals for the Tenth Circuit relied on clause (6) of rule 60(b), however, to grant relief on this ground in Pierce v. Cook $\mathcal{G}^{\mathrm{C}} \mathrm{Co}_{\mathrm{r}}{ }^{2}$ in which parties to a common catastrophe litigated to different conclusions in federal and state courts due to earlier resolution in the federal courts and a subsequent change of the controlling precedent in the state courts.

Pierce involved a vehicular accident which occurred on January 11, 1968, in Oklahoma. Ted Pierce was killed and passengers in his car were injured in a collision with an independent contractor who was transporting wheat for defendant-appellee Cook. Pierce's widow, Claudiatte Pierce, and Pierce's passengers, Davis and Ellenwood, brought suit against Cook in an Oklahoma state court. On Cook's motion, each suit was removed to federal court on grounds of diversity of citizenship. The Davis suit was dismissed on plaintiff's motion and refiled in state court by coguardians of Davis, a minor. Because the guardianship destroyed diversity, it precluded removal to federal court. Claudiatte Pierce and Ellenwood were unsuccessful on the merits

1 FED. R. Crv. P. 60(b) now provides in part:

Mistakes; Inadvertence; Excusable Neglect; Newly Discovered Evidence; Fraud, etc. On motion and upon such terms as are just, the court may relieve a party or his legal representative from a final judgment, order, or proceeding for the following reasons: (1) mistake, inadvertence, surprise, or excusable neglect; (2) newly discovered evidence which by due diligence could not have been discovered in time to move for a new trial under Rule 59(b); (3) fraud (whether heretofore denominated intrinsic or extrinsic), misrepresentation, or other misconduct of an adverse party; (4) the judgment is void; (5) the judgment has been satisfied, released, or discharged, or a prior judgment upon which it is based has been reversed or otherwise vacated, or it is no longer equitable that the judgment should have prospective application; or (6) any other reason justifying relief from the operation of the judgment. The motion shall be made within a reasonable time, and for reasons (1), (2) and (3) not more than one year after the judgment, order, or proceeding was entered or taken. A motion under this subdivision (b) does not affect the finality of a judgment or suspend its operation . 1976).

${ }^{2} 518$ F.2d 720 (10th Cir. 1975), cert. denied, 44 U.S.L.W. 3412 (U.S. Jan. 19, 
in the federal district court, which awarded Cook summary judgment on the basis of Oklahoma precedent established in Marion Machine, Foundry E Supply Co. v. Duncan $;^{3}$ the Tenth Circuit affirmed. ${ }^{4}$ The decision of the circuit court became final in January, 1971. The state trial court in the Davis suit also granted Cook summary judgment, finding Marion Machine controlling. On appeal the Oklahoma Supreme Court specifically overruled Marion Machine and remanded the suit for jury trial. ${ }^{5}$ The case was then settled favorably to plaintiff Davis.

The Oklahoma Supreme Court judgment became final in May, 1974. In November, 1974, Claudiatte Pierce and Ellenwood filed a rule 60 (b) motion with the Tenth Circuit, seeking relief from the judgment of that court as a matter of law. The Tenth Circuit, sitting en banc, held that the movants were entitled to relief from the circuit court's judgment under rule $60(\mathrm{~b})(6)$ because the federal courts in which they were forced to litigate treated them substantially differently than the state supreme court treated another person injured in the same accident, contrary to the command of Erie Railroad $v$. Tompkins ${ }^{6}$ and the interest of justice. The case was remanded to the district court which was directed, upon movants' filing of the motion below, to consider the rule $60(\mathrm{~b})(6)$ motion as one for relief from the trial court's judgment in light of the supervening Oklahoma decision and the opinion of the Tenth Circuit.

Thus Pierce presents the question whether rule 60(b)(6) relief from a federal judgment in a diversity case is required either by the Erie doctrine or by the need to correct the inequity of divergent results on the same or similar facts, when the state law relied upon by the federal court is subsequently altered.

\section{Relief Under Rule 60(b)(6) Generally}

When relief may properly be granted under clause (6) of rule 60 (b) depends on the function of the rule as a whole and on the relationship of clause (6) to the preceding five clauses. Rule 60 (b) in its present form ${ }^{7}$ embodies a balancing of the conflicting

${ }^{3} 187$ Okla. 160,101 P.2d 813 (1940).

${ }^{4}$ Pierce v. Cook \& Co. 437 F.2d 1119 (10th Cir. 1970).

${ }^{5}$ Hudgens v. Cook Industries, Inc., 521 P.2d 813 (Okla. 1973).

6304 U.S. 64 (1938). Compare text accompanying notes 59-66 infra with text accompanying notes 93-121 infra.

${ }^{7}$ Note 1 supra. The substance of rule $60(\mathrm{~b})$ in its present form is the product of the 1946 amendments. In 1948, the rule was insignificantly amended by the substitution of its present statutory reference, "Title 28 U.S.C $\$ 1655$," for its former citation, "Section 57 of the Judicial Code, U.S.C., Title 28, § 118 ." See J. Moore, Federal Practice Rules Pamphlet pt. 1, at 1071 (1975) [hereinafter cited as Rules Pamphlet]. 
values of finality of judgments and provision of relief from judgments when justice so requires. ${ }^{8}$ Original rule $60(\mathrm{~b})$ established a six-month limit on the commencement of proceedings for seeking relief from final judgments. ${ }^{9}$ Although the rule effectively lengthened the period of time during which a court had control over its judgments, the grounds for relief were not expanded beyond those previously existing at common law. ${ }^{10}$ The courts soon devised ways to evade the six-month time limitation imposed by rule 60(b). Rule 6(b), allowing courts to extend time limits stipulated by the rules, was applied by the courts to rule 60(b); the "inherent power" of courts over their judgments was invoked when the courts wished to grant relief unavailable under the rule; and the ancillary remedies existing prior to the enactment of the Federal Rules were read into rule $60(\mathrm{~b}) .{ }^{11}$

In the 1946 amendments, the Advisory Committee established "reasonable time" limits, not to exceed one year, for motions under clauses (1)-(3) while motions under clauses (4)-(6) were made subject only to a "reasonable time" requirement.12 Rule 6(b) was amended to prohibit the extension of the maximum time periods prescribed by rule $60(\mathrm{~b}) .{ }^{13}$ Relief previously available by ancillary remedies was incorporated into rule 60(b). ${ }^{14}$ Under the 1946 amendments, relief was to be obtained exclusively by motion under one of the six clauses of rule $60(\mathrm{~b})$ or by an independent action to enjoin enforcement of the judgment. ${ }^{15}$ The sixth clause, upon which the Tenth Circuit relied in Pierce, is a residual clause which was inserted to provide relief in unforeseen circumstances. ${ }^{16}$

According to the prevailing interpretation of rule $60(\mathrm{~b})(6)$,

${ }^{8}$ Bankers Mortgage Co. v. United States, 423 F.2d 73, 77 (5th Cir.), cert. denied, 399 U.S. 927 (1970); 7 J. Moore, Federal Practice fl 60.18[2], at 203 (2d ed. 1975); Comment, Rule 60(b): Survey and Proposal for General Reform, 60 CAL. L. REv. 531, 533 (1972).

$97 \mathrm{~J}$. Moore, supra note 8, 960.09 , at 10-10.1.

${ }^{10}$ Comment, Civil Procedure-Federal Rules 60(b)(5) \& (6)-Applicability to Change of Law Situation, 44 Iowa L. Rev. 574, 574-75 (1959).

${ }_{11}$ Note, Federal Rule 60(b): Relief From Civil Judgments, 61 YALE L.J. 76, 78 (1952). For a discussion of original rule 60(b), see $7 \mathrm{~J}$. MOoRE, supra note 8, โI 60.10-.17 at 10.1-94; Comment, supra note 8, at 535-37; Comment, Temporal Aspects of the Finality of Judgments-The Significance of Federal Rule 60(b), 17 U. CHI. L. REv. 664, 668-69 (1950).

12 FED. R. Civ. P. 60(b); see 7 J. Moore, supra note 8, If 60.27[3], at 378.

${ }^{13}$ See Rules Pamphlet, supra note 7, at 1076.

${ }^{14}$ See 7 J. Moore, supra note 8, I 60.18[8], at 224-25; 58 Mich. L. Rev. 793, 794 (1960). The grounds for relief under clauses (1)-(3) were historically equitable, those under clauses (4) \& (5) were historically legal, while clause (6) "invokes the pure equity power of the court." Comment, Equitable Power of a Federal Court to Vacate a Final Judgment for "Any Other Reason Justifying Relief"-Rule 60b(6), 33 Mo. L. REv. 427, 434-35 (1968).

$157 \mathrm{~J}$. MOoRE, supra note 8, ๆ 60.18[8], at 225; Comment, supra note 8, at 537.

${ }^{16} 7 \mathrm{~J}$. MOORE, supra note 8, ๆ 60.27[2], at 353-54. 
relief cannot be granted under that clause on a ground covered by any of the first five clauses. In Klapprott $v$. United States, ${ }^{17}$ the first Supreme Court case construing rule 60(b)(6), Justice Black stated that "the language of the 'other reason' clause, for all reasons except the five particularly specified, vests power in courts adequate to enable them to vacate judgments whenever such action is appropriate to accomplish justice." 18 This view was reaffirmed by the Court a year later in Ackermann $v$. United States,${ }^{19}$ this time over Justice Black's dissent. ${ }^{20}$ Construing clause (6) and clauses (1)-(5) to be mutually exclusive is consistent with the scheme of time limits in the whole rule and the wording of clause (6): If relief could be granted on the same facts under either clauses (1)-(3) or clause (6), the purpose of the one year time limitation on clauses (1)-(3) would be undermined, and the word "other" in clause (6) would be meaningless. ${ }^{21}$

17335 U.S. 601, modified, 336 U.S. 942 (1949). The district court entered a denaturalization decree against Klapprott by default. Due to incarceration and illness Klapprott had been unable to attend the denaturalization proceedings or to petition for relief from the decree for more than four years after the issuance of the decree. The district court dismissed Klapprott's subsequent petition to set aside the judgment because of laches, and the court of appeals affirmed. The Supreme Court reversed and remanded with directions to determine the veracity of the allegations contained in the petition to vacate the default judgment.

${ }^{18}$ Id. at $614-15$.

19340 U.S. 193 (1950). The district court entered judgments cancelling the naturalization certificates of petitioner, his wife, and a relative. Petitioner and his wife failed to appeal because of lack of funds. The relative's decree was subsequently reversed on appeal. Then, more than four years after entry of the judgment against the petitioner, he petitioned the district court to vacate the judgment of denaturalization. The district court denied petitioner's rule 60(b) motion for relief, and the court of appeals affirmed. The Supreme Court upheld the decisions of the lower courts.

${ }^{20}$ Repudiating the literal effect of his Klapprott opinion, Justice Black argued that the specified grounds for relief in rule $60(\mathrm{~b})(1)-(5)$ were not intended to prevent the granting of similar relief in other situations where justice so requires. Id. at 202-03 (Black, J., dissenting). Consistent with Justice Black's dissent, Judge Hand in United States v. Karahalias, 205 F.2d 331 (2d Cir. 1953), read rule 60(b)(6) "to provide for situations of extreme hardship, not only those, if there be any, that subsections (1), (2) and (3) do not cover, but those that they do." Id. at 333. On rehearing, however, Judge Hand noted the divergence of his interpretation of rule $60(\mathrm{~b})(6)$ from the majority's reasoning in Klapprott and retracted the opinion to that extent. Id. at 335.

Not all courts, however, conscientiously adhere to the mutual exclusivity principle. See, e.g., Tozer v. Charles A. Krause Milling Co., 189 F.2d 242 (3d Cir. 1951) (relief granted on motion under $60(\mathrm{~b})(1)$ and (6) without rejecting either clause); Nelms v. Baltimore \& Ohio R.R., 11 F.R.D. 441 (N.D. Ohio 1951) (relief granted under 60(b) without identifying a specific clause).

${ }^{21}$ Klapprott v. United States, 335 U.S. 601, 626 (Reed, \& Jackson, JJ., \& Vinson, C.J., dissenting), modified, 336 U.S. 942 (1949); Gambocz v. Elimyer, 438 F.2d 915, 917 (3d Cir.), cert. denied, 403 U.S. 919 (1971); Federal Deposit Ins. Corp. v. Alker, 30 F.R.D. 527, 532 (E.D. Pa. 1962), aff'd, 316 F.2d 236 (3d Cir.), cert. denied, 375 U.S. 880 (1963); 7 J. MOORE, supra note 8 , I 60.27 [1], at 343-44. 
The language of rule $60(\mathrm{~b})(6)$ requires not only that the reason for relief fall outside of the preceding five clauses, but also that the reason be one "justifying relief." Justice Black's opinion in Klapprott contains broad language to the effect that rule $60(b)(6)$ should be applied to afford relief "whenever such action is appropriate to accomplish justice."22 Thus, courts commonly hold that rule 60(b), and specifically clause (6), should be interpreted liberally to do justice in particular cases. ${ }^{23}$ But Justice Black's opinion also observed that the facts before the Court presented an "extraordinary situation." 24 The Court later emphasized this aspect of the Klapprott case in denying rule $60(\mathrm{~b})(6)$ relief in Ackermann, making an "extraordinary situation" a requirement for rule $60(\mathrm{~b})(6)$ relief. ${ }^{25}$

In addition, several general principles must be considered in determining whether a party should be relieved of a judgment under rule $60(\mathrm{~b})(6)$ or any of the preceding clauses. Consideration must be given to the principle of finality of judgments; ${ }^{26}$ rule 60 (b) cannot be used as a substitute for appeal;27 justification must be shown for failure to resort to other remedies; ${ }^{28}$ a rule $60(\mathrm{~b})$ motion must be made within a reasonable time; ${ }^{29}$ and consideration must be given to any prejudice that might result to the other party, ${ }^{30}$ to any intervening equities that would make it unjust to grant relief, ${ }^{31}$ and to any other factors affecting the equities of the case. ${ }^{32}$

22335 U.S. at 615.

${ }^{23}$ E.g., Radack v. Norwegian America Line Agency, Inc., 318 F.2d 538, 542 (2d Cir. 1963); Erick Rios Bridoux v. Eastern Air Lines, Inc., 214 F.2d 207, 210 (D.C. Cir.), cert. denied, 348 U.S. 821 (1954); Tozer v. Charles A. Krause Milling Co., 189 F.2d 242, 245 (3d Cir. 1951); 7 J. MOoRE, supra note 8, I 60.27[1], at 342.

24335 U.S. at 613.

${ }^{25}$ See, e.g., Wagner v. United States, 316 F.2d 871, 872 (2d Cir. 1963); Collins v. City of Wichita, 254 F.2d 837, 839 (10th Cir. 1958); Loucke v. United States, 21 F.R.D. 305, 308 (S.D.N.Y. 1957). See generally Elgin Nat'l Watch Co. v. Barrett, 213 F.2d 776 (5th Cir. 1954).

${ }^{26}$ See, e.g., Ackermann v. United States, 340 U.S. 193, 198 (1950); Collins v. City of Wichita, 254 F.2d 837, 839 (10th Cir. 1958).

${ }^{27}$ See Ackermann v. United States, 340 U.S. 193, 198 (1950); Rinieri v. News Syndicate Co., 385 F.2d 818, 822 (2d Cir. 1967).

${ }^{28} 7 \mathrm{~J}$. Moore, supra note 8, I 60.27[1], at 348-49, I 60.28[2], at 403; Wham, Federal District Court Rule 60(b): A Humane Rule Gone Wrong, 49 A.B.A.J. 566 (1963).

${ }^{29} 7 \mathrm{~J}$. MOORE, supra note 8, 960.27 [3], at 378 .

${ }^{30}$ E.g., Pierre v. Bernuth Lembcke Co., 20 F.R.D. 116, 117 (S.D.N.Y. 1956); Comment, supra note 8 , at $\mathbf{5 6 5}$.

${ }^{31}$ E.g., Albion-Idaho Land Co. v. Adams, 58 F. Supp. 579, 581-82 (D. Idaho 1945).

$327 \mathrm{~J}$. MOORE, supra note 8, ๆ $60.27[1]$, at 351. 


\section{Operation of the Mutual Exclusivity} Requirement in the Change of Law Context

\section{A. Implications of the Requirement}

Because the reasons for relief under rule $60(\mathrm{~b})(6)$ must be exclusive of those under clauses (1)-(5), a supervening change of law must be shown to be outside of the scope of any of the first five clauses if it is to serve as a ground for relief under clause (6). Although a grant of relief under any of the six clauses would bring the same result, the clause relied upon must be determined. First, strict adherence to the doctrine of mutual exclusivity could result in a denial of relief when the rule 60 (b) motion is filed after one year from the entry of the judgment, as it was in Pierce, if the change of law ground were found to be subsumed under one of the first three clauses. Little practical difference would result, however, if the change of law ground were covered by clauses (4) or (5) rather than clause (6), because motions under these three provisions are subject to the same flexible limit of "reasonable time." 33 Second, alleged grounds for relief not enumerated in the first five clauses are subject to the "extraordinary situation" requirement established for rule $60(\mathrm{~b})(6)$ by the Supreme Court. ${ }^{34}$

Arguments have been made that a judgment may be set aside on the ground of a supervening change in controlling law under clauses (1) and (5) of rule 60(b). As demonstrated below, these arguments fail to establish that rule $60(\mathrm{~b})(6)$ relief in a change of law situation is precluded by the mutual exclusivity principle.

\section{B. Relief Under Rule $60(b)(1)$}

Professor Moore asserts that relief from judgments because of a post-judgment change in the applicable law may be available under $60(\mathrm{~b})(1)$ in a limited class of cases. ${ }^{35}$ Moore's position is based upon a construction of the word "mistake" in $60(\mathrm{~b})(1)$ that includes a substantive error of law by the court. ${ }^{36}$ Original rule 60(b) provided for relief when the moving party had made an error of law but not when the error was made by the court. Relief from judicial error was still available by the common law remedy of the bill of review for error apparent upon the record,

\footnotetext{
${ }^{33} I d .960 .27[1]$, at 346.

${ }^{34}$ See text accompanying notes 22-25 supra. See also Wham, supra note 28, at 567.

${ }^{35} 7 \mathrm{~J}$. Moore, supra note 8, ๆ $60.22[3]$, at 258-67.

${ }^{36}$ Id. ๆ $60.22[3]$, at 260.
} 
left standing by the saving clause of original rule $60(\mathrm{~b}){ }^{37}$ Moore asserts that although the bill of review did not afford relief in a change of law situation because the error was not apparent upon the record, new rule $60(\mathrm{~b})(1)$ should not be limited by the practice under the bill of review because the word "mistake" in the new rule is broader than the term "error of law apparent upon the record." 38 In deference to the principle of finality and the general rule that $60(\mathrm{~b})$ is not a substitute for appeal, Moore suggests that the definition of "reasonable time," which has an upper bound of one year for $60(\mathrm{~b})(1)$, should be further limited so as never to exceed the time allowed for appeal from the judgment. ${ }^{39}$ Consequently, a moving party could not circumvent the time limits for appeal by bringing a rule $60(\mathrm{~b})$ motion after the time allowed for appeal had expired. The advantage of affording relief under rule $60(\mathrm{~b})(1)$ for judicial error would be the avoidance of the inconvenience and expense of an appeal when the trial court is prepared to correct its own error. ${ }^{40}$

The question arises whether, in circuits subscribing to Moore's interpretation of rule $60(\mathrm{~b})(1)$, judgments can be set aside under rule $60(\mathrm{~b})(6)$ on the basis of a supervening change in controlling law without violence to the mutual exclusivity principle. To allow relief after the challenged judgment has been affirmed on appeal, as in the Pierce case, would transgress neither the requirement that rule $60(\mathrm{~b})$ not serve as a substitute for appeal nor the principle of mutual exclusivity. The first requirement is satisfied because relief is granted only after the moving party has diligently, though unsuccessfully, pursued his remedy of appeal. ${ }^{41}$ The doctrine of mutual exclusivity is re-

${ }^{37}$ Id.

${ }^{38}$ Id. 261.

${ }^{39} I d$. Cases in which rule 60(b) relief was granted under the conditions proposed by Professor Moore include Tarkington v. United States Lines Co., 222 F.2d 358 (2d Cir. 1955) and Oliver v. Monsanto Co., 56 F.R.D. 370 (S.D. Tex. 1972), aff'd, 487 F.2d 514 (5th Cir. 1973).

$407 \mathrm{~J}$. MOORE, supra note $8, \uparrow 60.22[3]$, at 260 .

41 To require the moving party to appeal the judgment in order to qualify for rule 60(b)(6) relief, however, would not be beneficial. If the trial judge has correctly applied the law that is soon to be changed but still is controlling during the time for appeal, bringing a futile appeal will accomplish little. See Polites v. United States, 364 U.S. 426, 437-38 (1960) (Brennan, J., dissenting). But see id. at 431-33 (majority opinion suggesting that such an appeal must be taken).

Even if an appeal were not required, other principles of law may limit the amount of time available to a petitioner who has justifiably chosen not to appeal. For example, how long would such a case remain sub judice? See text accompanying notes 67-90 infra. In the Pierce case petitioners did bring an appeal; a full discussion of the problems presented by the failure to appeal is beyond the scope of this Comment. 
spected because the supervening change in law upon which $60(b)(6)$ relief is based occurred after an appeal was taken and thus was not in existence during the time prescribed by Moore for relief under rule $60(\mathrm{~b})(1)$. In addition, unlike the conditions underlying the traditional bases of relief under clauses (1)-(3), which are discoverable and hence remediable within one year after entry of a judgment, at least in theory, a change of law leading to the motion for relief under clause (6) may not even materialize until the time limit on the first three clauses has expired. Therefore, it is fallacious to presume that relief was available under rule $60(\mathrm{~b})(1)$. Thus a court that construes rule 60 (b)(1) to provide relief in a change of law situation before the time for appeal has run is not necessarily barred by the doctrine of mutual exclusivity from granting relief under rule $60(b)(6)$ in response to a supervening change of law after the judgment has been appealed.

\section{Relief Under Rule $60(b)(5)$}

The moving parties in Pierce urged rule 60(b)(5) as an alternative basis for relief but the majority ignored this argument in its opinion. ${ }^{42}$ Although the language of the two component clauses of rule 60(b)(5) may appear at first reading to allow relief in a change of law situation, such relief is not available on that ground except in limited situations.

The first clause authorizes relief when "a prior judgment upon which the challenged judgment is based has been reversed or otherwise vacated ...." 43 A judgment must have been explicitly and directly based on a prior reversed judgment to be set aside under this clause. A change in controlling law after entry of the judgment does not satisfy this requirement. ${ }^{44}$ In reaching this result, the First Circuit in Lubben v. Selective Service System ${ }^{45}$

${ }^{42}$ Chief Judge Lewis, dissenting in Pierce, criticized the court's reliance on rule $60(\mathrm{~b})(6)$ when the moving parties sought relief only under rule $60(\mathrm{~b})(5) .518 \mathrm{~F} .2 \mathrm{~d}$ at 725 (Lewis, C.J., dissenting). The majority, in determining whether the movants presented facts justifying relief under any of the clauses of rule $60(\mathrm{~b})$ rather then denying relief because the movants used the wrong nomenclature, followed the better course. See $7 \mathrm{~J}$. MOORE, supra note $8, \uparrow 60.18[8]$, at 216.1 (nomenclature is unimportant); e.g., United States v. Jacobs, 298 F.2d 469, 472-73 (4th Cir. 1961) (60(b) relief granted even without a rule 60(b) motion); In re Cremidas' Estate, 14 F.R.D. 15 (D. Alas. 1953) (60(b) relief granted on petition for a writ of coram nobis).

${ }^{43}$ FED. R. Civ. P. 60(b)(5).

${ }^{44}$ Berryhill v. United States, 199 F.2d 217, 219 (6th Cir. 1952); Loucke v. United States, 21 F.R.D. 305, 307-08 (S.D.N.Y. 1957); Comment, rupra note 10, at 575-77; Note, Federal Rule 60(b): Finality of Civil Judgments 7 . Self-Correction by District Court of Judicial Error of Law, 43 Notre DaMe LAw. 98, 104 (1967).

${ }^{45} 453$ F.2d 645 (1st Cir. 1972). 
described the requisite relationship between the prior and subsequent judgments:

For a decision to be "based on" a prior judgment within the meaning of Rule $60(\mathrm{~b})(5)$, the prior judgment must be a necessary element of the decision, giving rise, for example, to the cause of action or a successful defense. . . . It is not sufficient that the prior judgment provides only precedent for the decision.

... [A] change in applicable law does not provide sufficient basis for relief under Rule $60(\mathrm{~b})(5){ }^{46}$

The second relevant clause of $60(\mathrm{~b})(5)$ allows relief from a judgment when "it is no longer equitable that the judgment should have prospective application ...." ${ }^{47}$ This provision is used primarily for relief from permanent injunctions; ${ }^{48}$ it encompasses cases in which a change of law makes the continuance of an injunction inequitable. ${ }^{49}$ Although this provision is not limited to equitable decrees, a judgment may not be brought within its purview unless it has a prospective application. ${ }^{50}$

Because the Pierce case involved a judgment neither directly based on a previously reversed judgment nor intended for prospective application, relief under rule $60(\mathrm{~b})(5)$ would not have been proper. Thus relief under rule $60(\mathrm{~b})(6)$ did not violate the principle of mutual exclusivity.

\section{Change in Applicable Law as a Reason “Justifying RELIEF" UNDER Rule 60(b)(6)}

\section{A. The Pierce Rationale}

Even when the mutual exclusivity test has been satisfied, rule $60(\mathrm{~b})(6)$ relief must be justified under equitable principles, ${ }^{51}$ including a showing of an "extraordinary situation." 52 The court

${ }^{46} I d$. at 650 (citations omitted).

${ }^{47}$ FED. R. Crv. P. 60(b)(5).

${ }^{48}$ Comment, supra note 10, at 576; see Elgin Nat'l Watch Co. v. Barrett, 213 F.2d 776, 780 (5th Cir. 1954).

$497 \mathrm{~J}$. Moore, supra note $8, \uparrow 60.26[4]$, at 335-36 (especially apt when a federal injunction is based on state law that has changed).

${ }^{50}$ Id. 337; see Polities v. United States, 364 U.S. 426, 438 (1960) (Brennan, J., dissenting, argued that relief was appropriate under rule $60(\mathrm{~b})(5)$ because the challenged judgment, a denaturalization decree, determined status affecting future conduct); Note, supra note 44 , at 105 .

${ }^{51}$ See text accompanying notes $26-32$ supra.

${ }^{52}$ See text accompanying notes 24 \& 25 supra. 
in Pierce held that the supervening change in state law justified relief under rule $60(\mathrm{~b})(6)$ because (1) otherwise the inconsistency of results in the state and federal courts on the same facts in a diversity case would violate the "outcome determination principle mandated by Erie v. Tompkins," 53 and (2) different treatment by the state and federal courts of persons injured in the same accident would be unjust. ${ }^{\mathbf{5 4}}$

Pierce represents a significant departure from prior interpretations of rule $60(\mathrm{~b})(6)$ in holding that a change in controlling law is cause for setting aside a final judgment. Relief in a change of law situation has been denied even when the applicant diligently pursued his remedy of appeal ${ }^{55}$ or lacked the financial resources to appeal.56 Despite considerable equities on the side of the moving party, the interest in finality of judgments has prevailed. ${ }^{57}$ Pierce is all the more remarkable because, rather than treat the motion before the court as a request for leave to file a motion for relief with the district court, whose ruling on the motion would be subject to review only for an abuse of discretion, the court of appeals granted relief from its judgment as a matter of law. ${ }^{58}$ The Pierce rationale, however, provides shaky support at best for its exceptional holding.

${ }^{53}$ Pierce v. Cook \& Co. 518 F.2d 720, 723 (10th Cir. 1975) (citing Erie R.R. v. Tompkins, 304 U.S. 64 (1938)). Compare text accompanying notes 59-66 infra with text accompanying notes 93-121 infra.

${ }^{54} 518$ F.2d at 723. See text accompanying notes 94-1 12 infra.

${ }^{55}$ Collins v. City of Wichita, 254 F.2d 837 (10th Cir. 1958).

${ }^{56}$ Loucke v. United States, 21 F.R.D. 305 (S.D.N.Y. 1957); cf. Ackermann v. United States, 340 U.S. 193 (1950).

${ }^{57}$ Loucke v. United States, 21 F.R.D. 305, 310 (S.D.N.Y. 1957) ("situation with a measure of obvious human appeal').

${ }^{58} 518$ F.2d at 722 (majority oponion), 725 (Lewis, C.J., dissenting), 726 (Seth, J., dissenting). It is highly unusual for a circuit court to adjudicate the merits of a rule 60 (b) motion in the first instance. A rule 60 (b) motion is addressed to the sound discretion of the district court. E.g., Caribou Four Corners, Inc. v. Truck Ins. Exch., 443 F.2d 796, 799 (10th Cir. 1971); United States v. Jacobs, 298 F.2d 469, 473 (4th Cir. 1961). A question of law arises when the issue is whether the rule 60(b) motion was made within the time prescribed by the rule such that the district court had the power to grant relief, or when relief turns on such questions as the validity of a judgment; but when the decision to grant relief depends on a discretionary review of the facts of a particular case, the question is one for the district court. $7 \mathrm{~J}$. MOORE, supra note 8, I 60.30[1], at 418-19 \& n.13.

After the challenged judgment has been affirmed by a court of appeals, however, the district court cannot disturb the judgment without leave of the appellate court. Butcher \& Sherrerd v. Welsh, 206 F.2d 259, 262 (3d Cir. 1953), cert. denied, 346 U.S. 925 (1954). Because the rule 60(b) motion in Pierce was filed with the court of appeals, and because the grant or denial of relief depended on an appraisal of the facts, the court of appeals should have treated the motion as a petition for leave to file a motion with the district court. Tribble v. Bruin, 279 F.2d 424 (4th Cir. 1960); see United States v. Jacobs, 


\section{B. Reliance on Erie Railroad v. Tompkins}

\section{Application of the Basic Doctrine}

The decision in Erie Railroad v. Tompkins ${ }^{59}$ was rendered to guarantee that any case in federal court only because of diversity of citizenship would be decided according to the same substantive law by which it would have been decided had it been brought in state court. If the Pierce court held that Erie required rule $60(\mathrm{~b})(6)$ relief from judgment in the change of law situation before the court, ${ }^{60}$ such relief would be called for whenever a state court changed state law that had been applied by a federal court in a diversity case and was necessary to its decision. It is unlikely, however, that Erie requires retroactive application of state law to federal judgments that have been final for as long as the judgment in Pierce; and the availability of alternate remedies during the period in which Erie requires the retroactive application of state law ${ }^{61}$ makes relief under rule $60(\mathrm{~b})(6)$ inappropriate.

For Erie purposes, the Pierce case is indistinguishable from the more usual circumstances of an unrelated accident case in which analogous but unconnected suits are brought in state and federal courts, the federal case is resolved first, and the state supreme court alters the law applied by the federal court in the course of adjudicating the state case. Erie itself did not involve a common catastrophe; nor was it rendered only to ensure that

298 F.2d 469 (4th Cir. 1961). The cases cited by the majority in Pierce, 518 F.2d at 722 , discuss whether a district court must obtain leave of an appellate court before entertaining a rule 60 (b) motion; they do not support the court's action in hearing the merits of the motion in the first instance.

59304 U.S. 64 (1938).

${ }^{60}$ The court said: "The outcome determination principle mandated by Erie v. Tompkins has been violated." $518 \mathrm{~F} .2 \mathrm{~d}$ at 723 .

Whether Erie requires the retroactive application of a supervening change in state law in diversity cases is a separate question from whether a federal court must grant rule 60 (b) relief in circumstances in which a state court would allow comparable relief from its own judgment. Rule 60(b) is a valid rule of procedure under the Rule-Making Act, 28 U.S.C. § 2071 (1970); granting relief from a federal judgment is determined by the provisions of the rule, not by state policies concerning relief from state judgments. $7 \mathrm{~J}$. MOORE, supra note 8, I 60.18[8], at 218; 6A id. If 60.04[3], at 4049-51; cf. Hanna v. Plumer, 380 U.S. 460 (1965). Thus the issue in Pierce was not whether the state court would grant relief from its final judgment on the basis of a supervening change in state law, but whether relief was required on the facts as a matter of federal law. Relief under rule $60(b)$, granted to ensure that the currently controlling state substantive law will be applied, might result ironically in retroactive application of state law in which the state court itself would not engage. This "procedural" conflict is presumably permissible under Hanna.

${ }^{61}$ See text accompanying notes $68 \& 69$ infra. 
state substantive law would be applied to suits arising from common transactions being litigated simultaneously in state and federal courts. The Pierce holding is unsupported to the extent that its finding of an "extraordinary situation" is based on a view that Erie requires relief under rule $60(\mathrm{~b})(6)$ only when a federalstate divergence emerges from a common catastrophe. ${ }^{62}$ If the majority in Pierce meant not that relief was compelled by Erie, but only that the underlying policy of Erie of promoting uniform administration of the laws ${ }^{63}$ moved the court to grant relief, then Pierce would not be as far-reaching. ${ }^{64}$

The alternative posed by Judge Barrett in his concurring opinion in Pierce also fails to comport with Erie. Judge Barrett suggests that a change in state law should not be available as a ground for relief to a party who selected the federal forum voluntarily but only to a party forced to litigate in the federal courts. ${ }^{65}$ This argument is faulty if based on Erie and not simply on equitable considerations. ${ }^{66}$ The logical implication of Erie is that when state law is controlling, the party selecting the federal forum has the same right to correction of a retrospectively "erroneous" application of state law as the party who is in federal court "involuntarily." Erie determined that the decision whether to apply state or federal law is a matter of judicial power, not judicial discretion guided by a sense of fairness or by who brought suit in which court.

\section{Application of the Sub Judice Requirement}

In any case, Erie probably does not require vacation of a federal judgment, erroneous in retrospect because of a supervening change in state law, when the decisional change comes as long after entry of the federal judgment as it did in Pierce. ${ }^{67}$

\footnotetext{
62518 F.2d at 723 .
}

Chief Judge Lewis, dissenting from the decision in Pierce, takes this position:

The factual background of this case is based on a common disaster and ....

I assume that the majority ruling is intended to be limited by this "extraordinary circumstance." But the driving force of the ruling, the desire to obtain consistent results in state and federal cases involving state law, to me, seems equally applicable to identical accidents ....Id. at 725 (Lewis, C.J., dissenting).

Judge Seth, also dissenting in Pierce, expresses the same view: "The argument advanced by the majority is equally applicable to any diversity case, and the fortuitous circumstance of one accident makes no legal difference whatever ...." Id. at 726 (Seth, J., dissenting).

63 304 U.S. at 74-75.

${ }^{64}$ See text accompanying notes 93-121 infra.

65 518 F.2d at 724-25 (Barrett, J., concurring).

${ }^{66}$ See text accompanying notes 93-121 infra.

${ }^{67}$ The federal judgment became final in January, 1971, and the supervening state 
Under the Supreme Court ruling in Vandenbark $v$. Owens-Illinois Glass Co. ${ }^{68}$ federal courts must apply any recent changes in applicable state law "until such time as a case is no longer sub judice." 69 In Vandenbark, the Supreme Court reviewed a decision of the Court of Appeals for the Sixth Circuit ${ }^{70}$ not to reverse the district court's judgment in a diversity case after the state court decisions on which the district court relied were overruled by the state supreme court during the appeal. In reversing the decision of the Sixth Circuit the Court held:

Until such time as a case is no longer sub judice, the duty rests upon federal courts to apply state law under the Rules of Decision statute in accordance with the then controlling decision of the highest state court. Any other conclusion would but perpetuate the confusion and injustices arising from inconsistent federal and state interpretations of state law. ${ }^{71}$

After Vandenbark it appeared that a case was no longer sub judice once the judgment of a court of appeals had become final. Four years later, however, in Huddleston v. Dwyer, ${ }^{72}$ the Supreme Court made clear that recent pronouncements by a state supreme court must be applied to federal decisions even after entry of the judgment of a court of appeals. Petitioners in Huddleston filed a timely petition for rehearing with the Tenth Circuit after that court affirmed the judgment of the district court. $^{73}$ The petition was denied on September 1, 1943. On December 17,1943 , petitioners moved for leave by the circuit court to file a second petition for rehearing, because of a decision of the Supreme Court of Oklahoma ${ }^{74}$ on October 19, 1943, overruling an earlier decision that had been followed by the court of appeals in affirming the judgment of the district court. Petitioners' motion was denied. On certiorari, the Supreme Court vacated the judgment of the Tenth Circuit and remanded the case for reconsideration under the recent rulings of the Supreme Court of Oklahoma. The Court reaffirmed Vandenbark, quoting

judgment became final in May, 1974. The rule 60 (b) motion was filed in November, 1974.518 F.2d at 722.

68311 U.S. 538 (1941).

${ }^{69}$ Id. at 543 .

${ }^{70}$ Vandenbark v. Owens-Illinois Glass Co., 110 F.2d 310 (6th Cir. 1940).

71311 U.S. at 543 (footnote omitted).

72322 U.S. 232 (1944).

${ }^{73}$ Huddleston v. Dwyer, 137 F.2d 383 (10th Cir. 1943), rev'd, 322 U.S. 232 (1944).

74 Wilson v. City of Hollis, 193 Okla. 241, 142 P.2d 633 (1943). 
the requirement that the federal courts apply recent decisional law as long as the case remains sub judice. ${ }^{75}$

The Court of Appeals for the Second Circuit, interpreting Huddleston in Braniff Airways, Inc. $v$. Curtiss-Wright Corp. ${ }^{76}$ believed the Supreme Court to have "indicated that so long as the case was 'sub judice' the court of appeals should have entertained the petition for rehearing based on a change in state law; [the Supreme Court] did not indicate, however, precisely what the bounds of the term 'sub judice' might be."77 In Braniff a change in controlling state law occurred after entry of the judgment of the court of appeals. After the time for petitioning for rehearing by the court of appeals elapsed, petitioners filed a petition for certiorari; while that petition was still pending, they filed a motion with the court of appeals for modification of the judgment or for extension of the time to petition for rehearing. The court of appeals held that it had power under rules 26(b) and 40 of the Federal Rules of Appellate Procedure to extend the time to petition for rehearing and that it could modify an erroneous decision after the time for rehearing had expired. In addition, the court believed that Huddleston required it to grant the petition for rehearing and to consider the effect of the recent state ruling. ${ }^{78}$

Huddleston and Braniff read together do not necessarily extend indefinitely the period during which a case is sub judice. In Huddleston, the change in state law came prior to expiration of the time allowed for petitioning for certiorari, ${ }^{79}$ and the motion for leave to file the second petition for rehearing was filed within the sixty-day period by which the time for petitioning for certiorari could be extended. ${ }^{80}$ In Braniff, the motion for extension of the time to petition for rehearing was filed before the petition

75322 U.S. at 236.

${ }^{76} 424$ F.2d 427 (2d Cir.), cert. denied, 400 U.S. 829 (1970).

77 Id. at 429 .

${ }^{78} I d$. at $429-30$.

${ }^{79}$ When Huddleston was decided in 1943, the time allowed for petitioning for certiorari was "three months." Act of Feb. 13, 1925, ch. 229, § 8(a), 43 Stat. 940, as amended, 28 U.S.C. $\$ 2101$ (1970). Because the timely petition for rehearing filed by petitioners in Huddleston suspended the finality of the court's judgment, Department of Banking v. Pink, 317 U.S. 264, 266 (1942), the announcement of the Oklahoma decision in October was within the period allowed for petitioning for certiorari, which extended three months from the denial of the first petition for rehearing on September 1 .

${ }^{80}$ Act of Feb. 13,1925 , ch. $229, \S 8(\mathrm{a}), 43$ Stat. 940, as amended, 28 U.S.C. § 2101 (1970). The motion for leave was filed on December 17 which was within this extended period. The Supreme Court in Huddleston heard the case after expiration of the initial three-month period which began on September 1, see note 79 supra, and ended before filing of the motion for leave to file a petition for rehearing. 
for certiorari was disposed of by the Supreme Court. ${ }^{81}$ In both cases, then, review by the Supreme Court was still available short of the rehearing process.

The Supreme Court's practice of granting rehearings from its orders complicates the task of defining the time during which a case is sub judice. In Conner $v$. Simler, ${ }^{82}$ a diversity case, the Court granted a rehearing on its prior denial of certiorari and then vacated and remanded the case to the Tenth Circuit to consider the case in light of an Oklahoma Supreme Court decision handed down after the initial denial of certiorari. The Court's lack of explanation makes its action in Conner ambiguous, and a remand for consideration "in light of" is not a command to apply the new decision. ${ }^{83}$ Conner at least indicates that denial of certiorari does not terminate irrevocably the responsibility of the federal courts to consider supervening state decisions. But it may not be fruitful even to look to the deadline for petitioning for rehearing on a denial of certiorari as an outer limit for the period during which a case is sub judice, because the Court on occasion has disregarded its own rules concerning rehearings. ${ }^{84}$

On the other hand, the Court in Vandenbark must have contemplated some end to the period during which changes in state law have to be implemented retroactively by the federal courts. If a case were held to be sub judice whenever a motion pointing out supervening changes in state law was filed, the concept "sub judice" would become circular. A reasonable line might be drawn when a case is denied certiorari or decided on certiorari ${ }^{85}$ such that Supreme Court review is no longer available except through the rehearing procedure. ${ }^{86}$ The cases themselves suggest that a rule $60(\mathrm{~b})(6)$ motion addressed to the lower federal courts after this point may be inappropriate. Vandenbark, Huddleston, and Braniff had not reached disposition by the Supreme Court; the courts of appeals still had control over the cases and were held to be required by Erie to apply the newly interpreted state law. In Connors, on the other hand, the relief was requested after the denial of certiorari and the petition was directed not to the lower federal courts but to the Supreme Court itself. The Supreme

\footnotetext{
81424 F.2d at 429.

82367 U.S. 486 (1961), vacating and remanding 282 F.2d 382 (10th Cir. 1960).

${ }^{83}$ See The Supreme Court, 1960 Term, 75 Harv. L. REv. 40, 96 (1961).

${ }^{84}$ Gondeck v. Pan Am. World Airways, Inc., 382 U.S. 25 (1965).

${ }^{85}$ Cf. Collins v. City of Wichita, 254 F.2d 837 (10th Cir. 1958).

${ }^{86}$ See text accompanying notes 79-81 supra.
} 
Court's rehearing of the case with the subsequent vacation and remand appears to have been discretionary and the court of appeals was not required to apply but only to consider the new state opinion. If the case had still been sub judice, presumably the court of appeals would have been bound to apply the new law under Erie as interpreted in Vandenbark. ${ }^{87}$

In any event, the surprise and disruption that would result from retroactive application of state law beyond this point may outweigh the interest in exactly parallel application of state law. ${ }^{\mathbf{8 8}}$ In addition, because the state courts themselves might not apply their recent decisions to judgments they entered years before the change of law, discrimination might result between those who choose the federal forum and those who choose to stay in the state system in diversity cases. ${ }^{89}$

Although it is difficult to fix a precise point signifying the termination of the period during which a case is sub judice, the period in Pierce was beyond the range of reasonableness. In Pierce, the rule 60(b) motion was filed almost four years after the judgment of the Tenth Circuit became final. ${ }^{90}$ Moreover, during the limited period following entry of judgment by the court of appeals in which the federal courts arguably are bound to recognize supervening changes in state law, Huddleston and Braniff indicate that relief is available through a petition for rehearing addressed to the court of appeals. Normally rule 60 (b) relief is not available when other remedies exist.91 Relief under rule $60(\mathrm{~b})(6)$, an extreme remedy, ${ }^{92}$ is especially inappropriate in these circumstances.

\section{Role of Equitable Concerns}

To say that Erie does not require relief under rule 60(b)(6) on the facts of Pierce is not to deny that one of the policies underlying Erie-preventing inequitable administration of the laws ${ }^{93}$ - may be an adequate justification for allowing relief under rule $60(\mathrm{~b})(6)$ in a change of law situation. Accomplishing justice in particular cases is a major concern of rule $60(\mathrm{~b})$. In fact, remedying the inequity of inconsistent treatment by the

\footnotetext{
${ }^{87} 311$ U.S. at 543. See text accompanying notes $69-71$ supra.

${ }^{88}$ See The Supreme Court, 1960 Term, supra note 83, at 97.

${ }^{89}$ But see note 60 supra.

${ }^{90} 518 \mathrm{~F} .2 \mathrm{~d}$ at 722.

$917 \mathrm{~J}$. Moore, supra note 8, I 60.28[2], at 403; see Whara, supra note 28, at 566 .

92 Loucke v. United States, 21 F.R.D. 305, 308 (S.D.N.Y. 1957).

${ }^{93} 304$ U.S. at $74-75$.
} 
state and federal courts of parties to the same accident was a second motivating force behind the Pierce opinion. The question presented is whether Pierce truly is distinguishable on equitable grounds from situations involving unconnected but similar accidents, in which litigants in federal court are treated differently from litigants in state courts or even litigants in the same federal court at a later time, because of a supervening change in controlling law.

In reaching its decision in Pierce, the Tenth Circuit referred specifically to the unfairness of inconsistent treatment only briefly, by quoting from Gondeck v. Pan American World Airways, Inc. ${ }^{94}$ In that case, petitioner was awarded death benefits by the Department of Labor under the Longshoremen's and Harbor Workers' Compensation Act. ${ }^{95}$ The district court judgment setting aside the award was affirmed by the Fifth Circuit. ${ }^{96}$ The Supreme Court denied certiorari ${ }^{97}$ and the following term denied rehearing. ${ }^{98}$ The Fourth Circuit subsequently upheld an award to the survivors of another employee killed in the same accident. ${ }^{99}$ The Supreme Court then granted rehearing to the survivors of the first employee, granted certiorari, and reversed the judgment of the Fifth Circuit. Speaking of its deviation from United States Supreme Court Rule 58(2) concerning rehearings, the Court said: "[S]ince, of those eligible for compensation from the accident, this petitioner stands alone in not receiving it, 'the interests of justice would make unfair the strict application of our rules." "100 Judge Seth, dissenting in Pierce, may have been correct in his observation that the Supreme Court in Gondeck was simply acting in its supervisory capacity to require two circuits to construe a federal statute consistently. ${ }^{101}$ Yet the Court's language in Gondeck does emphasize the peculiar inequity in the different treatment of parties to the same event, which may have entered into the Court's determination to abandon its own rules and hear the case. ${ }^{102}$

Unfairness exists, however, in any case in which a superven-

94382 U.S. 25, 27 (1965), quoted in 518 F.2d at 723.

9533 U.S.C. $\$ \S 901-50(1970)$.

96299 F.2d 74 (5th Cir. 1962), rev'd, 382 U.S. 25 (1965).

97370 U.S. 918 (1962).

98371 U.S. 856 (1962).

${ }^{99}$ Pan Am. World Airways, Inc. v. O'Hearne, 355 F.2d 70 (4th Cir. 1964), cert. denied, 380 U.S. 950 (1965).

100382 U.S. at 27 (quoting United States v. Ohio Power Co., 353 U.S. 98, 99 (1957), quoted in 518 F.2d at 723.

101518 F.2d at 726 (Seth, J., dissenting).

102 See R. Stern \& E. Gressman, Supreme Court Practice 519 (4th ed. 1969). 
ing change of controlling law, state or federal, results in the incompatible treatment of persons similarly situated. ${ }^{103}$ In fact, two Justices of the Supreme Court found the equities more compelling in an unrelated accident case, Weed $v$. Bilbrey, ${ }^{104}$ than in Gondeck. In Weed, two men were killed in navigable waters in Florida in unconnected accidents. Weed, a widow of one of the men killed, was unsuccessful in the state courts with her claim that maritime law afforded a cause of action for wrongful death. The second widow, Moragne, litigated to the same conclusion in the federal courts. Weed preceded Moragne to the Supreme Court, but her first petition for certiorari was denied over three dissents. ${ }^{105}$ Three weeks later, Moragne raised the same claim in her petition for certiorari. Weed's petition for rehearing, asking that her claim be heard with Moragne's, was denied. ${ }^{106}$ Subsequently, certiorari was granted in the Moragne case. ${ }^{107}$ Weed was denied leave to file a second petition for rehearing. ${ }^{108}$ Thereafter, Moragne prevailed in the Supreme Court. ${ }^{109}$ Justice Douglas, joined by Justice Black, dissented from the denial of Weed's third petition for rehearing:

Every plaintiff who loses his claim cannot reinstate his action when a rule of law favorable to him is declared, either by the legislature or the court. But that is not what is attempted here. . . The facts of this case are even more compelling than those in Gondeck .... . Moreover, had Mrs. Weed proceeded through the federal courts, or had she instituted her suit later, she might have arrived in this Court after Mrs. Moragne. ${ }^{110}$

The majority's decision not to grant a rehearing in Weed, despite having granted a rehearing in Gondeck, does not necessarily imply that the majority disagreed with Justices Douglas and Black on the issue of fairness. The results in the two cases are reconcilable independently of the equities because Supreme Court review was required in Gondeck to resolve a conflict in the circuits $^{111}$ but was unnecessary in Weed because the pertinent

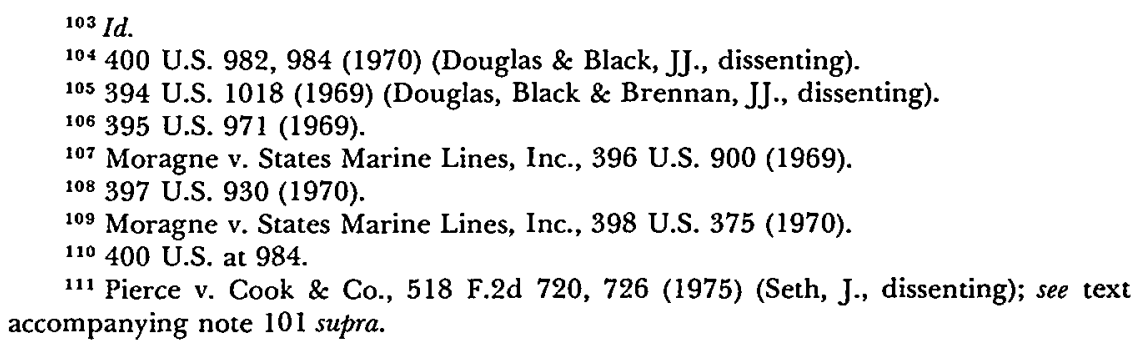


legal issue was raised in Moragne. ${ }^{112}$ The position of the dissenting Justices in Weed suggests that an unrelated accident case may present as strong a case for relief as a related accident case like Gondeck or Pierce. At least, the subjective perception that denial of relief would result in greater unfairness to the moving party in a related accident case than in an unrelated accident case is not sufficiently persuasive to establish the former as an extraordinary situation as a matter of law.

If the distinction between cases of related and unrelated accidents in terms of fairness to the unsuccessful party is too amorphous to justify an exception to the general practice of not allowing rule $60(\mathrm{~b})$ relief in a change of law situation, perhaps the Pierce decision may be justified by the differing degrees of prejudice to the prevailing party occasioned by granting relief in the two types of cases. In the Pierce situation, the defendant secured a favorable judgment in the federal courts earlier than in the state courts. His expectations about the finality of the federal judgment may have been less crystalized than those of a prevailing party who had all claims growing out of the same event litigated in a single court. The split litigation in Pierce may have given rise to a sense of nonfinality until all adjudication arising from the accident had been consummated. When perceptions of finality are still tentative, setting aside a judgment rendered early in the course of multiple-action litigation on the basis of later determinations may be considered not to encroach severely upon the interest in finality of judgments.

The subjective sense of unfairness to the unsuccessful party in a related accident case and the absence of substantial prejudice to the prevailing party are probably necessary but not sufficient to justify the holding in Pierce. In Ackermann, ${ }^{113}$ for example, the Supreme Court upheld the denial of rule $60(\mathrm{~b})(6)$ relief to the petitioner from a denaturalization decree even though the denaturalization judgment against the petitioner's relative, issued in the same proceeding, had been reversed on appeal. The petitioner claimed that he had been unable to appeal because of financial hardship, but the Court regarded the decision not to

${ }^{112}$ See also United States v. Maryland ex rel. Meyer, 382 U.S. 158 (1965), in which the Court granted leave to file a conditional petition for rehearing pending the Court's decision in Maryland ex rel. Levin v. United States, 381 U.S. 41, vacated, 382 U.S. 159 (1965), which involved a conflicting decision by another circuit growing out of the same accident, and then reversed after deciding Levin. The Court decided to hear both cases because they not only involved a common accident but were litigated on a single record. 381 U.S. at 43.

${ }^{113}$ Ackermann v. United States, 340 U.S. 193 (1950). 
appeal as a free choice and therefore fatal to his plea for relief. ${ }^{114}$ Thus, Ackermann involved disparate treatment of persons who not only were similarly situated but whose denaturalization decrees were issued in the same judicial proceeding, when little prejudice would have resulted to the prevailing party, the Government, had relief been granted.

The court in Pierce may also have been concerned with the element of free choice. ${ }^{115}$ The majority notes twice in its opinion that plaintiffs were "forced" into the federal forum where they could not utilize the "strategem" of urging that state precedent be overruled that the plaintiff employed in the state courts. ${ }^{116}$ Judge Barrett would have voted to deny relief had the plaintiffs chosen the federal forum in the first instance. ${ }^{117}$ In fact, Judge Barrett would grant rule $60(\mathrm{~b})(6)$ relief to a party who did not voluntarily choose the federal forum whenever that party would have prevailed in state court, apparently even in an unrelated accident case. ${ }^{118}$

It is difficult to say, then, just what rule Pierce purports to announce. The mere fact of divergent results in state and federal courts in cases arising from the same accident, singled out by the majority as the distinguishing feature of the case, ${ }^{119}$ may not be sufficient to merit relief under rule $60(\mathrm{~b})(6)$. The absence of free choice in being in the federal forum may have been a critical factor in the determination to grant relief. Countervailing considerations may require the denial of relief even in a related accident case. The presumption that the prevailing party's expectations of finality are weaker in a related accident case than in an unrelated accident case may be refuted by actions taken in reliance on the first judgment. In addition, when the party prevailing in the first decision in parallel suits growing out of a common catastrophe is not a party to the second suit, his expectations about the finality of his judgment are substantial, because litigation terminated for him with the first judgment. Finally, Collins v. City of Wichita, ${ }^{120}$ distinguished in Pierce as a case involv-

${ }^{114}$ Id. at 198.

${ }^{115}$ In Pierce the absence of freedom was in the choice of forum, not the decision whether to appeal.

116518 F.2d at 723 .

${ }^{117} \mathrm{Id}$. at 724-25 (Barrett, J., concurring); see text accompanying notes $65 \& 66$ supra.

${ }^{118} 518 \mathrm{~F} .2 \mathrm{~d}$ at $724-25$.

$119 \mathrm{Id}$. at 723 .

120254 F.2d 837 (10th Cir. 1958). 
ing unrelated transactions, ${ }^{121}$ concerned property rights whose existence in a case involving related transactions might make rule $60(\mathrm{~b})(6)$ relief inequitable.

Although the decision in Pierce might not have been impeachable as an abuse of discretion if handed down by a district court, the decision of the court of appeals is not persuasive as a matter of law. It is by no means clear which facts, if any, constituted the extraordinary situation prerequisite to relief under rule $60(b)(6)$.

\section{ConClusion}

Whether relief should be granted under rule 60(b)(6) when inconsistent results are reached in state and federal courts in suits arising from a common catastrophe is still an open question after Pierce. Such relief is not barred by the requirement that grounds for relief under clause (6) be exclusive of grounds covered by clauses (1)-(5), nor by the prohibition of the use of rule 60 (b) as a substitute for appeal, if relief is granted after the case has been heard on appeal. On the other hand, such relief is not required by Erie beyond a limited time after entry of the judgment of a court of appeals, and within that time alternate remedies are available. Consequently, if an exception is to be made to the general rule against rule $60(\mathrm{~b})(6)$ relief from judgments in a change of law situation, it must be based on equitable grounds. Although a presumption that expectations of finality are weak in common catastrophe litigation might weigh in favor of relief in a case like Pierce, a just decision can only be reached by a careful balancing of all the competing equities in a particular case.

121518 F.2d at 722-23. 